\title{
Williams 症候群例における顔記憶の障害に関する検討
}

\author{
中 道 和 輝 ${ }^{*}$ 細 川 徹 ${ }^{* *}$
}

\begin{abstract}
要旨 : Williams 症候群（WS） とは, 7 番染色体 7q11.23 領域の微小欠失に起因する隣接遺伝子症候群で ある。特徵的な社会的認知特性を持ち, 比較的良好な顔認知能力を有するとされるが, 顔の長期記憶につ いては十分な検討が行われていない。本研究では，1症例の WS と定型発達成人男性（TD） 24 名，知的 障害者（ID） 4 名を対象に，顔の短期記憶（STM）と長期記憶（LTM）について詳細な検討を行った。 その結果， STM ではWS の成績は ID 群よりも高くTD 群と同程度であったが, LTM ではTD 群よりも 低く ID 群と同程度であった。WS の LTM での反応の詳細を検証すると，WS は既知顔に関するヒット率 が高い一方，未知顔に関するフォルスアラーム率も高いという結果が認められた。WS は顔の記憶におい て未知顔であっても既知顔であるとみなしやすく，既知・未知に関わらず顔刺激全般に対して反応バイア スを有するのかもしれない。

(高次脳機能研究 36 (3) : 440 449, 2016)
\end{abstract}

Key Words : Williams 症候群, 顔記憶, hypersociability, 反応バイアス

Williams syndrome, face memory, hypersociability, response bias

\section{はじめに}

Williams 症候群（Williams syndrome:WS）とは, エラスチン遺伝子を含む 7 番染色体 $7 \mathrm{q} 11.23$ 領域の 半接合体欠失に起因する神経発達障害である（Curran ら 1993, Ewart ら 1993, Olson ら 1993)。WS の発症頻度は, 一般に出生数 $20,000 \sim 30,000$ 人あ たり 1 人といわれるが，北欧の母集団を対象とする 研究では出生数 7,500 人あたり 1 人とされている (Stromme ら 2002)。WS は，一般に軽度から中等 度の知的発達障害（IQ 30〜 IQ 70）を伴い, 妖精 様顔貌（elfin face）と呼ばれる特徵的な顔つきをし ていることが多く, 大動脈弁上狭窄などの心血管異 常を伴うことも多い（Burn 1986）。また，WSは 過度の社交性（hypersociability）とも表現される社 会的認知特性を持ち, 他者への高い関心・近づきや すさを示すことが知られている (Jarvinen-Pasley ら 2010, Jones ら 2000, Mervis ら 2003)。さらに, WS の視空間認知能力は言語能力の良好さと比較し て著しく障害されているが (Bellugi ら 1994), 顔 認知の能力は比較的保たれていることも知られてい る(Bellugi ら 1994, Rose ら 2007)。しかしながら, WS における顔の記憶能力については，未だに十分 に検証されていない。本研究では, WSの 1 症例を
対象とし，顔の短期記憶，長期記憶について検証し た。

WS では, 一般的な視空間認知の障害と比較して 顔認知は保存されていることが多い (Bellugiら 1994, Rose ら 2007)。ある先行研究では，6つの 異なる顔写真から特定の夕ーゲットの顔を同定する 課題において, WS は健常成人群と同程度の成績を 示すことが報告されている（Bellugi ら 1994）。ま た別の研究では, 正立顔の同定能力を評価する課題 において, WS は定型発達児と比較して同程度の成 績であったことが示されている（Rose ら 2007）。 このような WS における顔認知の良好さは，WS 特 有の社交的な性格特性のために，幼少期から顔に注 意を向ける頻度が多くなるためであると解釈されて いる（Roseら 2007）。他方, WS では表情の認知 は必ずしも保たれているとはいえず，笑顔の認知は 比較的保たれているものの, 恐怖表情や怒り顔など ネガティブな表情の認知には困難を示すことも指摘 されている (Lacroix ら 2009, Plesa-Skwerer ら 2006)。したがって, WSにおける顔認知とそれに 伴う表情認知との関係については，未だに一致した 見解が得られておらず，不明な点が多いのが現状で ある。

WS における短期記憶や作業記憶に関する研究で 
は, いくつかの特徴的な解離のパターンが報告され ている。たとえば, WS は言語性短期記憶の課題に おいて, ダウン症 (Down syndrome : DS) 児と比 較して有意に高い成績を示すことが報告されている (Bellugi ら 1994)。その後の研究では, WS は言語 性短期記憶については中等度の学習障害を示す群と 比較して同等の成績を示し, 視覚性短期記憶課題で は学習障害児群や DS 児群と比較して成績が低下し ていたことから，WSにおける短期記憶の能力には， 言語性短期記憶と視覚性短期記憶の間で解離がある ことが示唆されている（Jarroldら 1999）。また, 顔刺激を使用した顔の形態に着目した作業記憶と顔 の空間的位置に着目した作業記憶とでは, WS は顔 の形態に関する作業記憶は保存されている一方で, 顔の空間的位置についての作業記憶は障害されてい たことが報告されている（Paulら 2002）。したが って, WS では顔以外の一般的な視覚対象を用いた 短期 (作業) 記憶は障害されている一方で, 顔の形 態に着目した短期 (作業) 記憶の能力は保存されて いることが示唆される。

WS における長期記憶に関する検討でも，いくつ かの特徴的な解離パターンが報告されている。たと えば, 言語性の長期記憶課題において WS は DS と 比較して高い成績を示すが（Bellugi ら 1994）, 定 型発達児との比較では, 初頭効果がみられず親近性 効果がみられることから, 言語性短期 (作業) 記憶 が保たれている一方で, 長期記憶が障害されている ことが指摘されている(Vicariら 1996)。またWSは, 精神年齢（mental age：MA）統制群と比較して視 空間性の長期記憶の学習が障害されているものの, 視覚形態の長期記憶の学習は保存されており, DS とは対照のパターンの障害を示すことが報告されて いる（Vicariら 2005）。しかし近年の報告では, WS は定型発達者と比較して言語性, 視覚性ともに 長期記憶の能力は障害されており（Sampaioら 2008), またDS と比較しても言語性, 視覚性とも に長期記憶の能力は障害されていることも示されて いる（Edginら 2010）。さらにWS では, 記憶素材 のモダリテイに関わらず，記憶記銘時の文脈情報な どの詳細な情報の想起過程を反映する回想（recollection）の過程による記憶の想起が, 記銘時の詳細 な情報を含まないが記憶に残っているという感覚を 反映する熟知性 (familiarity) と比較して, 有意に 低下していることも報告されている（Costanzo ら
2013)。しかしながら，WSにおける顔を用いた長 期記憶については未だに検証がなされておらず, 作 業記憶において認められたような顔記憶の優位性が 長期記憶においても認められるかは明らかにはなっ ていない。

本研究では, WSの 1 症例を対象として, 顔の短 期記憶および長期記憶の特徵を詳細に検討した結果 を報告する。

\section{I. 方 法}

\section{1. 症例}

Williams 症候群者 1 名 (男性) が本研究に参加し た。本症例の年齢は 28 歳, 14 歳時に FISH 法にて 第 7 染色体 q11.23 領域に欠失を認め, Williams 症 候群の確定診断を受けており, 特徵的な顔貌と大動 脈弁上狭窄を伴う典型的な WS 患者であった。本研 究参加時に実施されたWAIS-III による知能指数は, 全 IQ 49（言語性 IQ：58, 動作性 IQ：47）であり, 言語性 IQ と比較して動作性 IQ が低い值となって いた。また, WAIS-III の下位項目である積木模様 では評価点が 2 点で, 基準年齢群評価点の平均を大 きく下回っており, 大域・局所文字判別テスト (compound letter task) で用いられる, 大域と局所 からなる 2 階層のアルファベットの模写を行う課題 (Delis hierarchical processing task) でも，WSにお いて典型的ともいえる全体の構成に困難を示した (図 1)。さらに, 本症例では自閉的特徴は認められ ず, 幼少期から WS 特有の過度の社交性や聴覚過敏 傾向, 音楽嗜好性が認められ, 臨床的な観察からも 典型的な WS であることが示唆された (Korenberg ら 2000)。なお, 日常生活上では, 本症例の顔の認 知, および表情の認知に顕著な問題は認められなか った。

本症例の課題成績は, 健常若年成人（Typical Development：TD）男性 24 名 と非 WS である知的障 害を有する（Intellectual Disability：ID）男性 4 名 と比較された。WS 症例と年齢, 性別を一致させた 統制群とするために, TD 群と ID 群には 20 歳台の 男性がリクルートされた。TD群の平均年齢は 22.17 歳 (範囲 : 20 〜 24 歳) であり, どの参加者 にも日常生活上で問題となる, 知的障害, 視覚障害, 聴覚障害は認められなかった。ID 群の平均年齢は 24.75 歳 (範囲: $21 \sim 30$ 歳) であり, 全員知的障 害を伴い, 精神発達遅滞の診断を有しており, 各参 

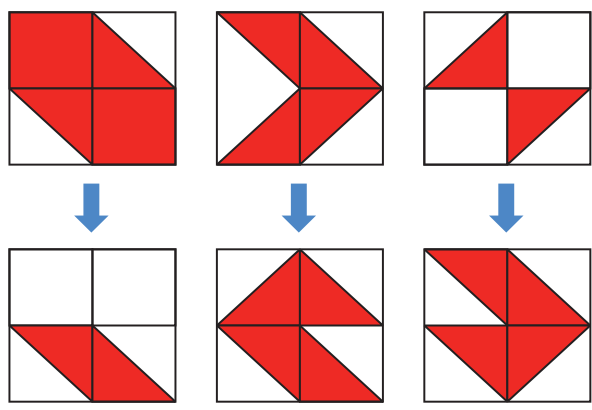

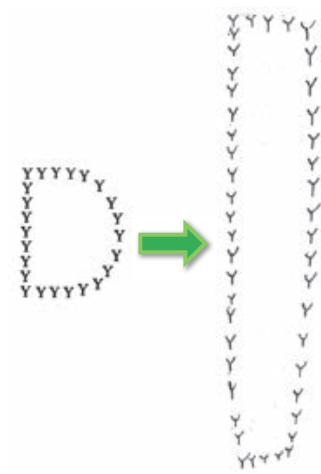

図1 本症例に実施したBlock design およびDelis hierarchical processing task の結果。 WS 特有の構成機能の障害および全体処理の障害が認められる。

表 1 WS 症例, TD 群, ID 群のプロフィール

\begin{tabular}{lccc}
\hline & WS & TD $(\mathrm{n}=24)$ & ID $(\mathrm{n}=4)$ \\
\hline \hline Chronological Age & & & \\
$\quad$ Mean & 28 & 22.17 & 24.75 \\
Range & - & $20-24$ & $21-30$ \\
WAIS-III & & & - \\
FIQ & 49 & - & - \\
VIQ & 58 & - & - \\
PIQ & 47 & - & \\
\hline
\end{tabular}

加者が在住する地方自治体から療育手帳の交付を受 けていた。WS 症例と TD, ID の各群のプロフィー ルを表 1 に示す。

\section{2. 刺激}

日本人 96 名分（男性 48 名および女性 48 名, 年 齢範囲：18〜 24 歳）の顔写真が刺激として用いら れた。これらの写真は, 研究内容に関する説明を行 い，同意を得られた者から顔写真を撮影することで 作成された。撮像されたすべての写真は額から顎に かけて，目・鼻・口・眉だけが見えるように加工さ れ，さらにモノクロ加工されたものが用いられた。 さらに, 顔刺激に加えて, レイヴン色彩マトリック ス検査で用いられている刺激から，容易に言語化す ることが困難な戝版が 96 枚選択され，それらをモ ノクロ加工することで刺激として用いられた。

\section{3. 手続き}

本研究で実施した課題の例を図 2 に示す。本研 究では, 短期記憶 (Short-Term Memory：STM） 課題と長期記憶（Long-Term Memory：LTM）課 題の 2 種類の課題が, 顔刺激と図形刺激に対して実
施された。STM 課題では, 刺激の即時再認を行う ことで短期記憶が評価され，LTM 課題では，STM 課題で提示された刺激に対しての遅延再認を行うこ とで，長期記憶が評価された。また，記憶の負荷の 違いによる成績の変化を考慮し，16 枚の刺激の即 時再認を行う 16 試行の STM 課題と 32 枚の刺激の 即時再認を行う 32 試行の STM 課題を行った。さ らに, それぞれのSTM 課題の後には, 同試行数の LTM 課題を行った。したがって, 各参加者は合計 8 つの課題（顔刺激と図形刺激のそれぞれで, 16 試 行と 32 試行の STM 課題およびLTM 課題) に参加 した。各課題の実施順序は参加者間でカウンターバ ランスされた。刺激の提示には, Critea VF-HG 17.3 inch 液 晶 $(1920 \times 1080)$ NVIDIA GeForce GT740M が使用され，刺激の提示タイミングは Presentation 16.5 (Neurobehavioral Systems, Inc.) によって制御された。顔写真は視野角 $4^{\circ} \times 5^{\circ}$, 図 形刺激は視野角 $5^{\circ} \times 4^{\circ}$ で, 参加者からは約 $50 \mathrm{~cm}$ の距離で白い背景の上に提示された。TD 群では, STM およびLTM の両課題においてそれぞれ練習試 行を 4 試行行い, WS・ID 群では, 課題内容を理解 するまで練習試行を繰り返した。STM 課題実施終 了から LTM 課題実施開始までの平均遅延時間は 6.6 分, 実験全体の所要時間は概ね 30 分であった。

STM 課題では，顔刺激および図形刺激に対する 即時再認が行われた。16 試行の課題では, 24 枚 16 組（同一刺激の組である Same 試行： $50 \%$ ，異なる 刺激の組であるDifferent 試行：50\%), 32 試行の 課題では, 48 枚 32 組（同一刺激の組である Same 試行： $50 \%$ ，異なる刺激の組である Different 試行： 


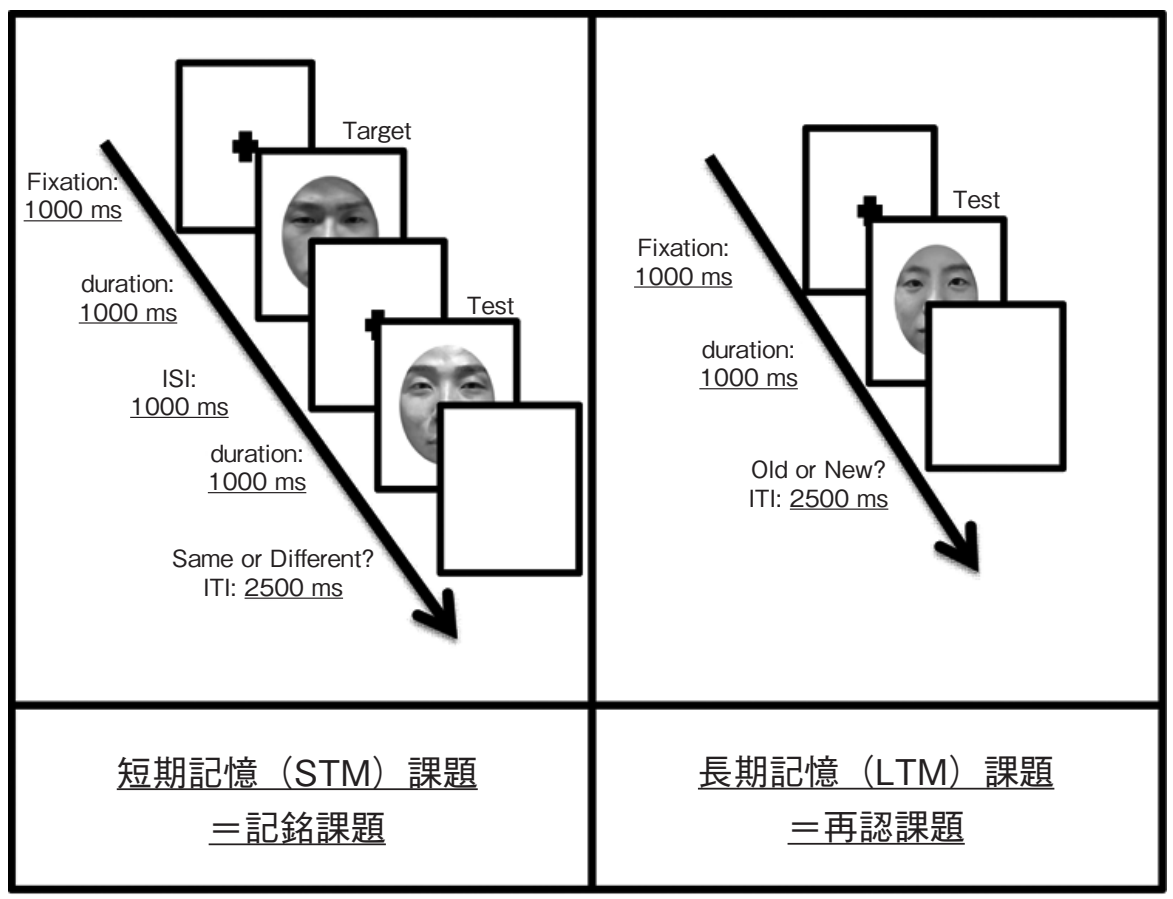

※顔刺激での課題例

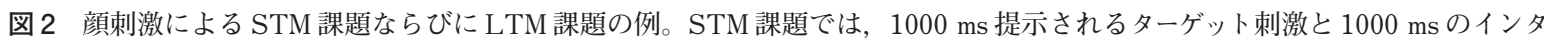
一バルを置いて $1000 \mathrm{~ms}$ 提示されるテスト刺激の異同判断を行い, LTM 課題では STM 課題で提示されたターゲット刺激 の半分と同数のディストラクター刺激に対して，「STM 課題で提示された刺激かどうか」の判断を行った。

50\%）の刺激を使用し，それぞれで顔刺激を用いた 課題と図形刺激を用いた課題を実施した。16 試行 の課題と 32 試行の課題とでは, それぞれ異なった 刺激セットを用い, それらの刺激セットは参加者間 でカウンターバランスされた。また, 刺激の提示順 序は参加者ごとにランダムに提示された。STM の 各試行では, 1 枚目のターゲット刺激が $1000 \mathrm{~ms}$ 提 示され，注視点が提示される $1000 \mathrm{~ms}$ の刺激間間隔 の後, 2 枚目のテスト刺激が $1000 \mathrm{~ms}$ 提示された。 参加者は, テスト刺激が 1 枚目のターゲット刺激と 同一の刺激か別の刺激かを判断するように教示さ れ，2枚目のテスト刺激が 1 枚目のターゲット刺激 と同じと判断した場合には, キーボードの赤いシー ルを貼ったキー（Fキー）を，違うと判断した場合 には青いシールを貼ったキー（Jキー）を押すよう に教示された。応答制限時間は TD 群では $2500 \mathrm{~ms}$ とし，WS および ID 群では応答が得られたことを 実験者が確認した後, 次の試行へ進んだ。ターゲッ 卜刺激とテスト刺激が一致する試行を Same 試行, ターゲット刺激とテスト刺激が一致しない試行を
Different 試行と定義した。

STM 課題の後に行われたLTM 課題では, STM 課題で提示された顔刺激および眓形刺激に対する遅 延再認が行われた。この課題では, STM 課題で提 示された刺激のうち Same 試行で提示された刺激と 同数の新規刺激が参加者ごとにランダムに提示され た。各試行では, 刺激は 1 枚ずつ $1000 \mathrm{~ms}$ 提示され, 参加者はその刺激が STM 課題で提示された刺激か どうかを判断することが求められた。参加者は, 提 示された刺激が STM 課題で提示された刺激だと判 断した場合にはキーボードの赤いキー（Fキー）を， 提示された刺激ではないと判断した場合には青いキ ー（Jキー）を押すように教示された。応答制限時 間は TD 群では $2500 \mathrm{~ms}$ とし, WS および ID 群で は応答が得られたことを実験者が確認した後, 次の 試行へ進んだ。

\section{4. 解析}

STM 課題では, Same 試行で反応したすべての試 行のうち,「同じ」と判断した試行がヒット (hit),「違 う」と判断した試行がミス (miss) と定義され，ヒ 
ット率 (hit 数 $/$ hit 数 + miss 数) が各参加者にお いて算出された。また，Different 試行で反応した したすべての試行のうち，「同じ」と判断した試行 がフォルスアラーム (false alarm : FA),「違う」と 判断した試行がコレクトリジェクション (correct rejection）と定義され，フォルスアラーム率（false alarm 数 / false alarm 数 + correct rejection 数) が 算出された。LTM 課題では, Old 刺激に反応した すべての試行のうち,「以前に提示された」と判断 した試行をヒット (hit),「以前に提示されていない」 と判断した試行をミス（miss）と定義して，参加者 ごとにヒット率（hit 数 $/$ hit 数 + miss 数）が算出 された。また，新規刺激に反応したすべての試行の うち，「以前に提示された」と判断した試行をフォ ルスアラーム (false alarm), 「以前に提示されてい ない」と判断した試行をコレクトリジェクション (correct rejection) と定義して, フォルスアラーム 率 (false alarm 数 $/$ false alarm 数 + correct rejection 数) が算出された。課題ごとに, $\mathrm{A}^{\prime}$ （A プライ ム）值を算出し, WS のヒット率，フォルスアラー ム率, $\mathrm{A}^{\prime}$ 值と, TD 群, ID 群のヒット率, フォル
スアラーム率, $\mathrm{A}^{\prime}$ 值の平均值を比較することで, WS における各課題の記憶成績の障害の程度が検証 された。

\section{II. 結 果}

WS およびTD 群, ID 群における各課題のヒット 率，フォルスアラーム率， $\mathrm{A}^{\prime}$ 值を表 2 に示す。ヒ ット率に関して, STM 課題では ID 群の成績は図形 刺激の 32 試行で TD 群の平均值の $1 \mathrm{SD}$ よりも低か ったものの, WS の成績は TD 群と同程度であった。 LTM 課題では, WS のヒット率は顔の 16 試行以外 の全条件において TD 群の平均值の $1 \mathrm{SD} よ り も$ 低 かったが, ID 群の平均值の $1 \mathrm{SD}$ の範囲内であった。

フォルスアラーム率に関しては, WS は STM 課 題では全条件においてほとんどフォルスアラームを 示さなかったが，LTM 課題では顔刺激において特 に, 16 試行において TD 群の平均值の $1 \mathrm{SD} よ り も$ 高いフォルスアラーム率を示し, 32 試行において も TD 群, ID 群の両群と比較し, それぞれの平均 值の $1 \mathrm{SD} よ り も$ 高いフォルスアラーム率を示した。

$\mathrm{A}^{\prime}$ 值に関しては, STM 課題では顔刺激において

表 2 各課題の Hit 率. $\mathrm{FA}$ 率 $\cdot \mathrm{A}^{\prime}$ 值

\begin{tabular}{|c|c|c|c|c|c|c|c|c|c|c|}
\hline \multicolumn{2}{|c|}{ Task } & \multicolumn{3}{|c|}{ WS } & \multicolumn{3}{|c|}{$\mathrm{TD}(S D)$} & \multicolumn{3}{|c|}{ ID $(S D)$} \\
\hline $\begin{array}{c}\text { Trial } \\
\text { number }\end{array}$ & Stimuli & Hit & FA & $\mathrm{A}^{\prime}$ & Hit & FA & $\mathrm{A}^{\prime}$ & Hit & FA & $\mathrm{A}^{\prime}$ \\
\hline \multicolumn{11}{|c|}{ Short-Term Memory Task } \\
\hline \multirow{2}{*}{16 trial } & Face & 100 & 0 & 1 & $\begin{array}{l}96.35 \\
(4.85)\end{array}$ & $\begin{array}{c}0.03 \\
(0.07)\end{array}$ & $\begin{array}{c}0.98 \\
(0.03)\end{array}$ & $\begin{array}{l}92.19 \\
(3.13)\end{array}$ & $\begin{array}{c}0.03 \\
(0.05)\end{array}$ & $\begin{array}{c}0.97 \\
(0.01)\end{array}$ \\
\hline & Figure & 100 & 0 & 1 & $\begin{array}{l}92.45 \\
(6.89)\end{array}$ & $\begin{array}{c}0.1 \\
(0.15)\end{array}$ & $\begin{array}{c}0.93 \\
(0.11)\end{array}$ & $\begin{array}{c}81.25 \\
(11.41)\end{array}$ & $\begin{array}{c}0.19 \\
(0.21)\end{array}$ & $\begin{array}{c}0.86 \\
(0.13)\end{array}$ \\
\hline \multirow{2}{*}{32 trial } & Face & 100 & 0 & 1 & $\begin{array}{l}97.53 \\
(3.05)\end{array}$ & $\begin{array}{c}0.03 \\
(0.04)\end{array}$ & $\begin{array}{c}0.99 \\
(0.02)\end{array}$ & $\begin{array}{l}95.31 \\
(1.80)\end{array}$ & $\begin{array}{c}0.06 \\
(0.04)\end{array}$ & $\begin{array}{c}0.97 \\
(0.02)\end{array}$ \\
\hline & Figure & 96.88 & 0.06 & 0.976 & $\begin{array}{l}93.23 \\
(4.87)\end{array}$ & $\begin{array}{c}0.08 \\
(0.07)\end{array}$ & $\begin{array}{c}0.96 \\
(0.03)\end{array}$ & $\begin{array}{c}80.47 \\
(10.33)\end{array}$ & $\begin{array}{l}0.25 \\
(0.2)\end{array}$ & $\begin{array}{c}0.84 \\
(0.13)\end{array}$ \\
\hline \multicolumn{11}{|c|}{ Long-Term Memory Task } \\
\hline \multirow{2}{*}{16 trial } & Face & 56.25 & 0.88 & 0.232 & $\begin{array}{c}67.71 \\
(12.32)\end{array}$ & $\begin{array}{c}0.38 \\
(0.17)\end{array}$ & $\begin{array}{c}0.7 \\
(0.18)\end{array}$ & $\begin{array}{l}48.44 \\
(9.38)\end{array}$ & $\begin{array}{c}0.69 \\
(0.21)\end{array}$ & $\begin{array}{c}0.35 \\
(0.16)\end{array}$ \\
\hline & Figure & 56.25 & 0.5 & 0.559 & $\begin{array}{c}70.57 \\
(10.82)\end{array}$ & $\begin{array}{c}0.37 \\
(0.18)\end{array}$ & $\begin{array}{c}0.72 \\
(0.17)\end{array}$ & $\begin{array}{l}64.06 \\
(9.38)\end{array}$ & $\begin{array}{c}0.44 \\
(0.11)\end{array}$ & $\begin{array}{c}0.66 \\
(0.08)\end{array}$ \\
\hline \multirow{2}{*}{32 trial } & Face & 53.13 & 0.81 & 0.263 & $\begin{array}{c}67.58 \\
(10.90)\end{array}$ & $\begin{array}{c}0.34 \\
(0.15)\end{array}$ & $\begin{array}{c}0.72 \\
(0.15)\end{array}$ & $\begin{array}{l}57.81 \\
(6.00)\end{array}$ & $\begin{array}{c}0.48 \\
(0.32)\end{array}$ & $\begin{array}{c}0.56 \\
(0.26)\end{array}$ \\
\hline & Figure & 59.38 & 0.44 & 0.635 & $\begin{array}{l}70.83 \\
(7.06)\end{array}$ & $\begin{array}{c}0.3 \\
(0.13)\end{array}$ & $\begin{array}{c}0.78 \\
(0.11)\end{array}$ & $\begin{array}{l}61.72 \\
(6.93)\end{array}$ & $\begin{array}{l}0.47 \\
(0.1)\end{array}$ & $\begin{array}{c}0.62 \\
(0.12)\end{array}$ \\
\hline
\end{tabular}

FA : false alarm 
はWS, TD 群, ID 群の間でほとんど差は認められず, 図形刺激においては，32 試行において ID 群で TD 群の平均值の $1 \mathrm{SD} よ り も$ 低い $\mathrm{A}^{\prime}$ 值が認められた(図 3-A)。LTM 課題では, 図形刺激の 16 試行の課題で, WS は ID 群の平均值の $1 \mathrm{SD}$ よりもわずかに低い $\mathrm{A}^{\prime}$ 值を示し, 32 試行の課題では, WS と ID 群で TD 群 の平均值の $1 \mathrm{SD}$ よりも低い $\mathrm{A}^{\prime}$ 徝が示された(図 3-B)。 また顔刺激において, WS は 16 試行の課題で TD 群 の平均值の $1 \mathrm{SD} よ り も$ 顕著に低い $\mathrm{A}^{\prime}$ 值を示し, 32 試行の課題では TD 群の平均值の $1 \mathrm{SD}$ よりも顕著 に低く, ID 群の平均值の $1 \mathrm{SD}$ と比較しても低い $\mathrm{A}^{\prime}$ 值を示した（図3-B）。

\section{III. 考察}

本研究では, WS 症例に対して顔の短期記憶と長 期記憶について詳細に検証した。その結果, 主に 2 つの結果が得られた。第 1 に, WS の短期記憶は他 の群と比較して保たれていたが，WS の長期記憶は 特に顔刺激を用いた場合に他の 2 群よりも低下して いた。第 2 に, WS において認められた顔の長期記 憶の低下は，WS におけるヒット率の低下よりもフ オルスアラーム率の増加に由来していることが示さ れた。これらのことは, WS における顔記憶の能力 は短期記憶と長期記憶との間で解離しており, 長期 記憶における顔記憶の低下は, 顔刺激に対して特異 的に認められる反応バイアスと関連があることを示 唆している。

\section{1. 短期記憶と長期記憶の解離について}

本研究では, WS の短期記憶は刺激の種類に関わ らず保存されていた。この結果は, 先行研究の結果 と一致していた (Roseら 2007)。この先行研究では,

(A)

STM

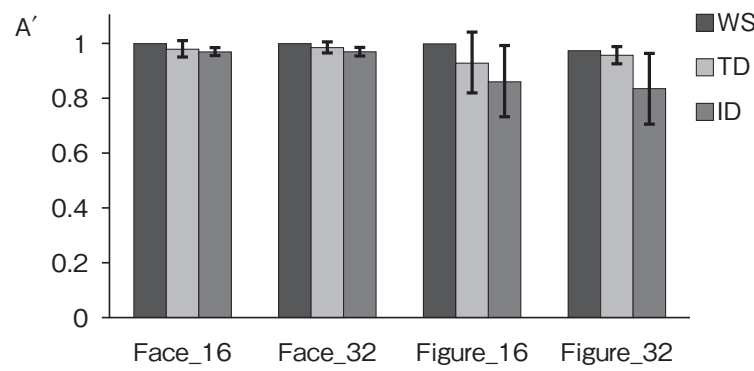

顔の形態に着目した作業記憶課題を行い, WS は定 型発達児と比較して同等の成績を示すことが報告さ れている。一方他の研究では, WS は定型発達児と 比較して, 立体的な視覚刺激や顔刺激などの短期記 憶が低下していたことが報告されている（O'Hearn ら 2009)。このような結果の不一致は, 空間位置の 情報へのアクセスが必要な視覚性短期記憶であるか 否かによって説明できるかもしれない。WSにおけ る短期記憶の成績低下を報告している先行研究では (O’Hearn ら 2009), 参加者は連続する刺激の同定 課題のみではなく, 連続する刺激の空間的位置が異 なって提示され, 参加者はこれらの刺激が同じ位置 に提示されていたかを判断するように求められ，刺 激提示位置を同定する課題で刺激の同定課題よりも WS の成績低下が認められている。またWS では, 視 覚の背側経路が障害されている可能性が, 行動学的 研究 (Atkinson ら 1997, Nakamura ら 2001, Paul ら2002）や脳機能画像研究から示されている (Meyer-Lindenberg ら 2004)。本研究での短期記 憶課題では, 参加者は顔刺激, 眓形刺激ともに形態 が一致しているかを判断するように求められてお り, 空間的位置の判断は必要とされていなかった。 したがって，WSでは視覚の腹側経路に関連する視 覚形態の処理を反映する視覚性短期記憶の処理能力 は保存されているが, その能力の保存は視覚の背側 経路に関連する空間位置の処理を必要としないよう な短期記憶課題に限定していると考えられる。

本研究における WS の長期記憶では, 特に顔刺激 を用いている場合に TD 群や ID 群と比較して低下 していることが示された。このことは, WSで一般 的に認められる顔認知能力の良好さや顔情報の短期

図 3 A. STM 課題に関する $\mathrm{A}^{\prime}$ 值。 B. LTM 課題に関する $\mathrm{A}^{\prime}$ 值。いずれも左から，顔刺激の 16 試行，顔刺激の 32 試行，図 形刺激の 16 試行, 眓形刺激の 32 試行における $\mathrm{A}^{\prime}$ 值を表している（TD 群・ID 群のエラーバーは各群の平均值士 $\left.1 \mathrm{SD}\right) 。$ 
記憶能力の保持が，必ずしもWSにおける顔の長期 記憶の成績へ反映しないことを示唆している。先行 研究では, WS において言語リストの長期記憶能力 が評価された場合に初頭効果が認められず親近性効 果のみが認められたことから, WS では短期記憶の 能力が保たれ，長期記憶能力が障害されていること が報告されている（Vicari ら 1996）。別の研究では, WS は定型発達児と比較して回想による記憶の想起 は低下しているのに対し, 熟知性による記憶の想起 は比較的保たれていることが報告されている (Costanzo ら 2013)。これらの先行研究の結果と本 研究の結果から, 図形刺激の再認では, 各図形の違 いが顕著なために熟知性の過程を用いた想起で正解 に至ることができるため，WS においても成績が低 下しないが，顔刺激では各刺激の視覚特性の違いが 小さいため, 正しく再認するためには回想過程によ る想起が必要であり，WS において成績が低下して いると考えられる。

\section{2. 長期記憶における反応バイアスについて}

本研究におけるもう一つの主な結果は, 顔の長期 記憶では先に記銘した顔に対するヒット率におい て, WS と ID 群との間には違いが認められなかっ たにも関わらず，先に記銘していない顔に対しての フォルスアラーム率については, WS では TD 群と ID 群の両群よりも増加していたということであっ た。このことは, WS では TD 群や ID 群と比較して, STM 課題で記銘していない新規の顔刺激に対して も以前に記銘した顔であると反応する，顕著な反応 バイアスを示す傾向があり，そのことが顔の長期記 憶の低下の一因となっていることを示唆している。

WS に打ける顔刺激への反応バイアス傾向は, WS における特徴的な行動特性として知られている hypersociability と関連があるのかもしれない。WS に認められる hypersociability とは, 同程度の知的障 害のある発達障害児と比較してより社交的であり， 共感性が高く, 親しくない他者に対してもあまり躊 躇せずに接近する傾向があることなどから示されて いる(Doyle ら 2004, Klein-Tasman ら 2003)。また, このような hypersociabilityの行動特性は, 顔写真 を提示して, その顔写真の人物に対して「近づいて 話しかけてみたいか」を問うような課題を行う実験 研究の場面でも一致して観察されている (Bellugi ら 1999, Jarvinen-Pasley ら 2010, Jones ら 2000)。 一般に, 定型発達者においても, 発達初期から顔刺
激に対する反応バイアスが認められることが報告さ れている（Mortonら 1991）が，WSにおいては生 活年齢（chronological age：CA）統制群や発達年齢 (developmental age：DA）統制群と比較して, 顔刺 激に対して顕著に注意のバイアスが高いことが示さ れており (Mervis ら 2003), 乳幼児期から hypersociability という行動特性が観察されることが示唆 されている。WSに打ける hypersociabilityに関連 する心理的要因については諸説あるが（Porter ら 2007)，その一つとして，社会的刺激に対して過敏 に反応する（social salience）という心理傾向が重 要な要因として考えられている (Frigerio ら 2006, Jarvinen ら 2013)。本研究におけるWS の反応バイ アスは顔刺激において顕著である一方で, 図形刺激 においてはそれほど顕著ではなかったことは，この social salience と関連があるのかもしれない。顔刺 激は視覚刺激のなかでも特別な刺激であり（Ellis 1975)，豊富な社会的情報を含んでいると考えられ ている (Haxby ら 2000, Todorov ら 2008)。さらに, WS は精神年齢（mental age：MA）統制群と比較 して, 言語的・動作的反応抑制課題において, 抑制 機能に困難を持つことが示されている（Carneyら 2013)。おそらく, WS は hypersociability の行動特 性に加え, その反応抑制の困難さのために, 社会的 刺激である顔刺激に対して反応バイアスを示し，そ の結果として顔刺激へのフォルスアラーム率が充進 し, 未知顔であっても既知顔と判断しやすくなるた めに, 顔記憶の成績が障害されたのだと考えられる。

\section{3. 本研究での WS 症例における日常生活におけ}

\section{る人の記憶について}

本研究では, WS 症例における顔記憶について系 統的に検証したが，本症例の日常生活上での顔認知 と顔記憶は, 限定された状況において比較的良好で あった。顔認知に関する仮説では (Bruceら 1986)， 最初に顔に対する情報の分析が行われた後, 顔のデ ータベースである顔再認ユニットにおいて，既に保 存されている既知顔と提示された顔の情報が照合さ れ，もし既知顔であった場合には，人物アイデンテ イティノードに拈いて職業などの人物の意味的な情 報が顔情報に付加され，最後にそれらの情報と名前 の音韻情報が名前コードにおいて連合され，その人 物の名前が生成されると考えられている。本症例は, 他者の顔や名前について優れた記憶力を持つが, 名 前の記憶は，実際に関わりを持った相手に限定され 
ていることが, 家族や友人への聞き取りから示唆さ れている。この仮説にしたがって，本研究における $\mathrm{WS}$ 症例の日常生活上での顔認知と顔記憶を解釈す ると, 本症例は顔再認ユニット, 人物アイデンティ ティノード, 名前コードといった 3 段階のプロセス を用いた顔認知機構による人物認知は比較的保存さ れているが，その機構は実際に関わりを持った人物 に対して限定されていることが示唆される。おそら く, WS における顔認知と顔記憶の日常生活上での 良好さは, 社会的状況下での他者との相互作用と密 接に結びついているのかもしれない。

\section{まとめ}

本研究では, WS における顔や顔以外の視覚刺激 に対する短期記憶と長期記憶について検証した。そ の結果, WS の視覚性短期記憶の処理能力は保存さ れているが, その能力の保存は空間位置の処理を必 要としないような短期記憶課題に限定されることが 示された。また WS の長期記憶は, 特に顔刺激の長 期記憶において顕著な低下が認められており, その 長期記憶の成績低下には, 記銘していない顔に対す るフォルスアラーム率の高さが関連しており, WS では未知顔であっても既知顔とみなしやすく, 未知・ 既知に関わらず, 顔刺激全般に対してのみ反応バイ アスを有することが示された。おそらく，WS 特有 の hypersociability と呼ばれる社会的認知特性が顔 刺激への反応バイアスを生じさせることで, WS に おける顔記憶が障害されているのかもしれない。

本稿の一部は, 第 38 回日本高次脳機能障害学会 学術総会（2014 年 11 月, 仙台) において発表され たものであり, 本論文は座長推薦により投稿したも のである。

謝辞 : 本研究に快くご協力くださいましたすべての 方々とそのご家族に深謝致します。本論文をまとめる にあたり，貴重なご助言ならびにご指導を賜りました 京都大学大学院人間・環境学研究科 月浦崇先生に深 謝致します。本研究の一部は, 文科省科研費・基盤研 究（B）（課題番号 25285188）による援助を受けました。

\section{文献}

1 ) Atkinson, J., King, J., Braddick, O., et al. : A specific deficit of dorsal stream function in Williams syndrome. Neuro- report, 8 : 1919-1922, 1997.

2 ) Bellugi, U., Wang, P. P. \& Jernigan, T. L. : Williams syndrome : An unusual neuropsychological profile. In : Atypical cognitive deficits in developmental disorders : Implications for brain function (eds Broman, S. \& Grafman, J.). Lawrence Erlbaum Associates, Hillsdale, NJ, 1994, pp. 159.

3 ) Bellugi, U., Adolphs, R., Cassady, C., et al. : Towards the neural basis for hypersociability in a genetic syndrome. Neuroreport, $10:$ 1653-1657, 1999.

4 ) Bruce, V. \& Young, A. : Understanding face recognition. Br. J. Psychol., $77:$ 305-327, 1986.

5 ) Burn, J. : Williams syndrome. J. Med. Genet., $23: 389-$ 395, 1986.

6 ) Carney, D. P., Brown, J. H. \& Henry, L. A. : Executive function in Williams and Down syndromes. Res. Dev. Disabil., $34:$ 46-55, 2013.

7 ) Costanzo, F., Vicari, S. \& Carlesimo, G. A. : Familiarity and recollection in Williams syndrome. Cortex, $49: 232-242$, 2013.

8 ) Curran, M. E., Atkinson, D. L., Ewart, A. K., et al. : The Elastin Gene Is Disrupted by a Translocation Associated with Supravalvular Aortic-Stenosis. Cell, 73 : 159-168, 1993.

9 ) Doyle, T. F., Bellugi, U., Korenberg, J. R., et al. : “Everybody in the world is my friend" hypersociability in young children with Williams syndrome. Am. J. Med. Genet., 124A : 263-273, 2004.

10) Edgin, J. O., Pennington, B. F. \& Mervis, C. B. : Neuropsychological components of intellectual disability : the contributions of immediate, working, and associative memory. J. Intellect. Disabil. Res., 54 : 406-417, 2010.

11) Ellis, H. D. : Recognizing faces. Br. J. Psychol., 66 : $409-$ 426, 1975.

12) Ewart, A. K., Morris, C. A., Atkinson, D., et al. : Hemizygosity at the Elastin Locus in a Developmental Disorder, Williams-Syndrome. Nat. Genet., 5 : 11-16, 1993.

13) Frigerio, E., Burt, D. M., Gagliardi, C., et al. : Is everybody always my friend? Perception of approachability in Williams syndrome. Neuropsychologia, $44: 254-259,2006$.

14) Haxby, J. V., Hoffman, E. A. \& Gobbini, M. I. : The distributed human neural system for face perception. Trends Cogn. Sci., 4 : 223-233, 2000.

15) Jarrold, C., Baddeley, A. D. \& Hewes, A. K. : Genetically dissociated components of working memory : evidence from Down's and Williams syndrome. Neuropsychologia, $37: 637-651,1999$.

16) Jarvinen-Pasley, A., Adolphs, R., Yam, A., et al. : Affiliative behavior in Williams syndrome : social perception and real-life social behavior. Neuropsychologia, $48: 2110$ 2119, 2010.

17) Jarvinen, A., Korenberg, J. R. \& Bellugi, U. : The social phenotype of Williams syndrome. Curr. Opin. Neurobiol., 
$23: 414-422,2013$.

18) Jones, W., Bellugi, U., Lai, Z., et al. : II. Hypersociability in Williams Syndrome. J. Cogn. Neurosci., 12 (Suppl 1) : 3046, 2000 .

19) Klein-Tasman, B. P. \& Mervis, C. B. : Distinctive personality characteristics of $8^{-}, 9^{-}$, and 10-year-olds with Williams syndrome. Dev. Neuropsychol., 23 : 269-290, 2003.

20) Korenberg, J. R., Chen, X. N., Hirota, H., et al. : VI. Genome structure and cognitive map of Williams syndrome. J. Cogn. Neurosci., 12 (Suppl 1) : 89-107, 2000.

21) Lacroix, A., Guidetti, M., Roge, B., et al. : Recognition of emotional and nonemotional facial expressions : a comparison between Williams syndrome and autism. Res. Dev. Disabil., 30 : 976-985, 2009.

22) Mervis, C. B., Morris, C. A., Klein-Tasman, B. P., et al. : Attentional characteristics of infants and toddlers with Williams syndrome during triadic interactions. Dev. Neuropsychol., $23:$ 243-268, 2003.

23) Meyer-Lindenberg, A., Kohn, P., Mervis, C. B., et al. : Neural basis of genetically determined visuospatial construction deficit in Williams syndrome. Neuron, $43: 623-$ 631, 2004.

24) Morton, J. \& Johnson, M. H. : CONSPEC and CONLERN : a two-process theory of infant face recognition. Psychol. Rev., 98 : 164-181, 1991.

25) Nakamura, M., Watanabe, K., Matsumoto, A., et al. : Williams syndrome and deficiency in visuospatial recognition. Dev. Med. Child Neurol., 43 : 617-621, 2001.

26) O'Hearn, K., Courtney, S., Street, W., et al. : Working memory impairment in people with Williams syndrome : effects of delay, task and stimuli. Brain Cogn., $69: 495-$ 503, 2009.

27) Olson, T. M., Michels, V. V., Lindor, N. M., et al. : Autosomal dominant supravalvular aortic stenosis : localization to chromosome 7. Hum. Mol. Genet., 2 : 869-873, 1993.

28) Paul, B. M., Stiles, J., Passarotti, A., et al. : Face and place processing in Williams syndrome : evidence for a dorsalventral dissociation. Neuroreport, $13: 1115-1119,2002$.

29) Plesa-Skwerer, D., Faja, S., Schofield, C., et al. : Perceiving facial and vocal expressions of emotion in individuals with Williams syndrome. Am. J. Ment. Retard., 111 : 15 26, 2006.

30) Porter, M. A., Coltheart, M. \& Langdon, R. : The neuropsychological basis of hypersociability in Williams and Down syndrome. Neuropsychologia, 45:2839-2849, 2007.

31) Rose, F. E., Lincoln, A. J., Lai, Z., et al. : Orientation and affective expression effects on face recognition in Williams syndrome and autism. J. Autism Dev. Disord., 37 : 513$522,2007$.

32) Sampaio, A., Sousa, N., Fernandez, M., et al. : Memory abilities in Williams syndrome : dissociation or developmental delay hypothesis? Brain Cogn., 66 : 290-297, 2008.

33) Stromme, P., Bjornstad, P. G. \& Ramstad, K. : Prevalence estimation of Williams syndrome. J. Child Neurol., 17 : 269-271, 2002.

34) Todorov, A., Said, C. P., Engell, A. D., et al. : Understanding evaluation of faces on social dimensions. Trends Cogn. Sci., 12 : 455-460, 2008.

35) Vicari, S., Bellucci, S. \& Carlesimo, G. A. : Visual and spatial long-term memory : differential pattern of impairments in Williams and Down syndromes. Dev. Med. Child Neurol., 47 : 305-311, 2005.

36) Vicari, S., Brizzolara, D., Carlesimo, G. A., et al. : Memory Abilities in Children with Williams Syndrome. Cortex, 32 : 503-514, 1996. 


\section{Abstract}

\section{Disturbance of face memories in a case with Williams syndrome Kazuki Nakamichi* Toru Hosokawa**}

Williams syndrome (WS) is a neurodevelopmental disorder caused by a hemizygous deletion in chromosome 7. Individuals with WS generally show a socio-cognitive trait known as "hypersociability", and are relatively preserved in perceiving facial stimuli. However, little is known about long-term memory for faces and its disturbance in WS. In the present study, we investigated short-term memories (STM) and long-term memories (LTM) for faces in a case with WS. In the STM tasks for faces, a case of WS showed higher scores than participants with intellectual disabilities (ID), and the score in WS was not different from scores in healthy participants with typical developments (TD). In the LTM tasks for faces, a case of WS performed worse than TD, and no difference was identified between WS and ID in the memory declines for facial stimuli. In addition, the detailed investigations for the LTM performance in WS demonstrated that WS showed higher rates of hits for familiar faces and false alarms for unfamiliar faces than TD and ID. These results suggest that individuals with WS could be likely to regard unknown faces as known faces, and to be biased toward facial stimuli even if the faces are unknown. The response bias toward facial stimuli could cause the lower performance of long-term memories for faces in WS.

\footnotetext{
${ }^{*}$ Graduate School of Human and Environmental Studies, Kyoto University. Yoshida-Nihonmatsu-Cho, Sakyo-ku, Kyoto 606-8501, Japan

*** Graduate School of Education, Tohoku University
} 